\title{
Influence of Tobacco Plant on Macronutrient Levels in Sandy Soils
}

\author{
Jacob Lisuma * ${ }^{\mathbb{D}}$, Ernest Mbega and Patrick Ndakidemi \\ Department of Sustainable Agriculture and Biodiversity Ecosystem Management, The Nelson Mandela African \\ Institution of Science and Technology (NM-AIST), P.O Box 447 Arusha, Tanzania; \\ ernest.mbega@nm-aist.ac.tz (E.M.); patrick.ndakidemi@nm-aist.ac.tz (P.N.) \\ * Correspondence: lisumaj@nm-aist.ac.tz; Tel.: +255-787-166-493
}

Received: 5 February 2020; Accepted: 29 February 2020; Published: 19 March 2020

\begin{abstract}
Tobacco (Nicotiana tabacum L.) is associated with great uptake of soil macronutrients. Following the need to understand the macronutrients levels before and after tobacco cultivation, research was conducted in loamy sand soil of Sikonge, Urambo, and sand soil of Tabora, Tanzania. The initial macronutrients levels in the soil were compared with those measured after unfertilized and fertilized tobacco. Results showed that unfertilized tobacco plant influences the increase of nicotine to the rhizosphere, the macronutrients $\mathrm{Ca}(135 \%)>\mathrm{N}(25 \%)$, decrease in the order of $\mathrm{S}(81 \%)$ $>\mathrm{P}(49 \%)>\mathrm{Mg}(12 \%)>\mathrm{K}(11 \%)$. The sole effect of nitrogen-phosphorus-potassium (NPK) and calcium-ammonium-nitrate (CAN) $27 \%$ fertilizers increased further nicotine, $\mathrm{Ca}(25 \%)>\mathrm{N}(20 \%)>\mathrm{S}$ $(8 \%)>\mathrm{Mg}(4 \%)>\mathrm{P}(3 \%)$, and decreased $\mathrm{K}(3 \%)$ in the rhizosphere. Both tobacco plant and NPK + CAN fertilizers on the rhizosphere increased Ca $(193 \%)>\mathrm{N}(50 \%)$ and decreased S $(80 \%)>\mathrm{P}(48 \%)>$ $\mathrm{K}(14 \%)>\mathrm{Mg}(8 \%)$. Leaf concentrations in fertilized tobacco increased Ca $(197 \%)>\mathrm{K}(28 \%)>\mathrm{P}(27 \%)$ $>\mathrm{S}(26 \%)>\mathrm{N}(18 \%)>\mathrm{Mg}(12 \%)$. Therefore, tobacco plant increases soil N and Ca but decreases P, $\mathrm{K}$, $\mathrm{Mg}$, and $\mathrm{S}$.
\end{abstract}

Keywords: rhizosphere; fertilizers; nutrients; soil fertility; soil/plant interactions; arable crops

\section{Introduction}

The tobacco (Nicotiana tabacum L.) plant requires large quantities of primary macronutrients such as nitrogen $(\mathrm{N})$, phosphorous $(\mathrm{P})$, and potassium $(\mathrm{K})$ and secondary macronutrients including calcium (Ca), magnesium (Mg), and sulphur $(\mathrm{S})$ in order to attain high leaf yield and good quality. Soil depletion of macronutrients is plausible because of the large input requirement to the tobacco crop [1-3]. The residual levels of other macronutrients, such as $\mathrm{Ca}$ and $\mathrm{Mg}$, have not been studied following tobacco production. Recently, investigators have reported an increase in total soil-N levels after tobacco cultivation [4,5], while others have reported a decline in soil macronutrients such as K, P, and $S$ [5-7]. The release of nicotine into the rhizosphere was considered to have a major impact on the increase or decrease of these nutrients. Thus, nicotine $\left(\mathrm{C}_{10} \mathrm{H}_{14} \mathrm{~N}_{2}\right)$ released in the soil could be mineralized and increase $\mathrm{N}$ in the soils, however, since nicotine is acidic, when mineralized could also influence solubilization of $\mathrm{P}, \mathrm{K}$, and $\mathrm{S}$ to be readily available to the plant and reduce their levels in the soil.

Nitrogen influences the growth and quality of flue-cured tobacco as well as the taste and aroma and the smoke [8-10]. The sufficient leaf concentration has been reported to range from $3.5 \%$ to $6.5 \%$ [11]. However, Haghighi et al. [12] observed N content in tobacco leaves to fluctuate from $2 \%$ to $5 \%$, and the deficiency symptoms to appear when $\mathrm{N}$ falls below $1.5 \%$. The recommendations for $\mathrm{N}$ application in tobacco ranges from 60 to $90 \mathrm{~kg} \mathrm{ha}^{-1}$ depending on topsoil depth, with lower rates required on shallow clay soils and higher rates needed on deep sands $[13,14]$. The nutrient $P$ is essential 
for hastening tobacco root development as well as improvement of the color and quality of leaves. The sufficiency concentration of $P$ in tobacco leaf ranges from $0.1 \%$ to $1.0 \%$ [11]. Studies have revealed that for optimum tobacco production, $\mathrm{P}$ must be supplied at an application rate of not more than $20 \mathrm{~kg} \mathrm{ha}^{-1}[13,14]$. The nutrient $\mathrm{K}$ influences leaf yield and quality of the tobacco [15]. The adequate foliar $\mathrm{K}$ range is from $1.6 \%$ to $4.1 \%$ for the tobacco [11], which typically requires a minimum of $100 \mathrm{~kg} \mathrm{~K}_{2} \mathrm{O} \mathrm{ha}^{-1}$ to obtain maximum yield and quality [13,14]. However, Vann et al. [16,17] indicated that the residual soil $\mathrm{K}$ and soil texture make it challenging to establish the actual amount of $\mathrm{K}$ to be supplied to optimize yields especially for the new cultivars bred as higher yielding.

Calcium has a strong influence on biomass and dry matter production in the tobacco plant. It is involved in the development of the cell wall, plasma membrane, cell growth, and enzyme secretion [18]. Calcium may also have a positive influence on $\mathrm{N}$ uptake and the activation of enzymes associated with $\mathrm{N}$ assimilation [4]. Sufficient foliar Ca concentrations range from $1.5 \%$ to $3.5 \%$ [11]. $\mathrm{Mg}$ is a constituent of the chlorophyll molecule, a co-factor of all enzymes involved in the phosphorylation reaction as well as being as an activator of several enzymes such as biphosphate carboxylase in triose sugar production [19]. The sufficient leaf concentrations for $\mathrm{Mg}$ are reported at $0.20 \%-0.85 \%$ [11]. S is essential for tobacco growth, development, and metabolism. $\mathrm{S}$ also regulates plant responses to various biological and non-biological stresses. Furthermore, $\mathrm{S}$ induces resistance to tobacco mosaic virus (TMV) in correlation with glutathione metabolism [20]. The adequate leaf concentrations for $S$ ranges from $0.18 \%$ to $0.50 \%$ [11].

Even though some studies have reported the tobacco crop to either deplete or increase macronutrients in soils $[1,2,4,5]$, none of these studies have investigated how tobacco plants affect soil chemistry and the levels of macronutrients in different soils [5,7]. Nor has previous research linked leaf nutrient concentrations to these factors. Therefore, the objective of this study was to investigate the effects of fertilizer application on soil macronutrient levels and leaf nutrient concentrations compared to non-fertilized tobacco systems. This study likewise took into account the effects of nicotine exudation into the rhizosphere and its impact on macronutrient availability. These findings may help tobacco growers make proper decisions when supplementing macronutrients for planting crops next to tobacco.

\section{Materials and Methods}

\subsection{Experimental Details and Treatments}

Field experiments were conducted in Sikonge District (had mean atmospheric temperature and rainfall of $29^{\circ} \mathrm{C}$ and $1050 \mathrm{~mm}$, respectively, located at $05^{\circ} 31^{\prime} 47.4^{\prime \prime} \mathrm{S}, 032^{\circ} 50^{\prime} 03.2^{\prime \prime} \mathrm{E} ; 1,191 \mathrm{~m}$ a.s.l.), Urambo District (had mean atmospheric temperature and rainfall of $25^{\circ} \mathrm{C}$ and $890 \mathrm{~mm}$, respectively, located at $05^{\circ} 04^{\prime} 33.5^{\prime \prime} \mathrm{S}, 032^{\circ} 00^{\prime} 09.8^{\prime \prime} \mathrm{E} ; 1,108 \mathrm{~m}$ a.s.l.), and Tabora District (had mean atmospheric temperature and rainfall of $27^{\circ} \mathrm{C}$ and $950 \mathrm{~mm}$, respectively, located at $05^{\circ} 03^{\prime} 44.4^{\prime \prime} \mathrm{S}, 032^{\circ} 40^{\prime} 07.4^{\prime \prime} \mathrm{E}$; $1160 \mathrm{~m}$ a.s.l.) sites, of Tabora region, Tanzania which grow tobacco as their commercial crop during the 2017/18 cropping season. The selected soil properties of the experimental area are given in Table 1 . Tobacco seed variety K326 was used from Tobacco Research Institute of Tanzania (TORITA).

Table 1. Selected soil properties of experimental soils before tobacco cultivation.

\begin{tabular}{cccccc}
\hline \multirow{2}{*}{ Description } & Measured Variables & Unit & \multicolumn{3}{c}{ Sites } \\
\cline { 4 - 6 } & & & Sikonge & Tabora & Urambo \\
\hline Soil $\mathrm{pH}$ & $\mathrm{pH}(1: 2.5)$ in $\mathrm{H}_{2} \mathrm{O}$ & & 5.89 & 5.49 & 5.87 \\
& Clay & $(\%)$ & 11.5 & 6.96 & 12.12 \\
Soil particle size & Silt & $(\%)$ & 3.48 & 4.64 & 2.92 \\
& Sand & $(\%)$ & 85.04 & 88.4 & 84.96 \\
Soil texture & Texture Class & & Loamy sand & Sand & Loamy sand \\
\hline
\end{tabular}


The seedlings were raised in a seedbed of $1.5 \times 20 \mathrm{~m}$ and fertilized with $5 \mathrm{~kg}$ of $\mathrm{N}_{10} \mathrm{P}_{18} \mathrm{~K}_{24}$ fertilizer. Eight weeks after sowing, the seedlings were transplanted to the experimental plots at a spacing of $1.2 \mathrm{~m}$ between ridges and $0.50 \mathrm{~m}$ between plants making the total of 60 plants per plot equivalent to 16,666 plants/ha. Fertilizers nitrogen-phosphorus-potassium (NPK) and calcium-ammonium-nitrate (CAN) were applied as treatments against unfertilized plots. Fertilizer $\mathrm{N}_{10} \mathrm{P}_{18} \mathrm{~K}_{24}$ at a rate of $30 \mathrm{~g}$ per plant was applied around the seedling at a distance of about $20 \mathrm{~cm}$ seven days after transplanting. This is equivalent to $50 \mathrm{~kg} \mathrm{~N}, 90 \mathrm{~kg} \mathrm{P}$, and $120 \mathrm{~kg} \mathrm{~K} \mathrm{ha}^{-1}$. Fertilizer CAN 27\% was applied at a rate of $8 \mathrm{~g}$ per plant two weeks after application of NPK in a similar way and position. This is equivalent to $33.75 \mathrm{~kg} \mathrm{~N}$ and $5.4 \mathrm{~kg} \mathrm{Ca} \mathrm{ha}^{-1}$.

The layout of the experiment was a randomized complete block design (RCBD) and the two treatments were replicated three times. The treatments were (1) fertilizers: (i) $\mathrm{N}_{10} \mathrm{P}_{18} \mathrm{~K}_{24}$ fertilizer blended with $\mathrm{B}, \mathrm{CaO}, \mathrm{MgO}$, and S; and (ii) calcium-ammonium-nitrate ( $\mathrm{CAN}+27 \mathrm{~N} \%$ ) blended with $\mathrm{CaO}, \mathrm{MgO}$, and $\mathrm{S}$ applied two weeks after application of NPK; and (2) unfertilized.

\subsection{Plant Leaf Sample Harvesting and Macronutrient Assessment}

A mature middle leaf in each tobacco plant was sampled such that the border rows and the first three plants at the edges of the inner rows were excluded. Of the three inner rows in each plot, the leaves were sampled from six plants hence 18 plants in a plot. Therefore, a total of 162 plants were sampled in the experimental site as there were plots for two fertilizer sources $\left(\mathrm{N}_{10} \mathrm{P}_{18} \mathrm{~K}_{24}\right.$ and CAN $27 \% \mathrm{~N}$ ) and unfertilized, all in three replications. These leaf samples were dried in the oven at $65^{\circ} \mathrm{C}$ at a constant weight. Chopping of the dried leaf samples was done and sieved with a $0.5 \mathrm{~mm}$ wire mesh. Dry ash and wet digestion laboratory analyses were performed for concentrations of $\mathrm{N}, \mathrm{P}, \mathrm{K}, \mathrm{Ca}, \mathrm{Mg}$, and S [21]. Soil properties, leaf nicotine concentration, and harvested leaf yield are presented for each research site as Supplementary Tables S1-S7 (Supplementary Materials).

\subsection{Soil Sampling Before the Experiment, After Harvesting Tobacco Leaves, and Assessment}

Soil samples from each treatment plot were taken by zig zag method in three locations to the depth of 0-20 cm. Composite soil samples at a depth of 0-20 cm were collected from experimental sites before and after experimentation. These soils were tested for the texture, soil $\mathrm{pH}$ was determined using soil water ratio 1:2.5, organic carbon (OC) was determined by Walkley Black method, and total $\mathrm{N}$ was determined by the Kjedahl method. Available P was determined by Bray-1 method, exchangeable Ca, $\mathrm{Mg}$, and extractable $\mathrm{S}$ was determined by Atomic Adsorption Spectophotometer. Thermo Scientific, iCE3300 AA System Serial No C113300088, Leicestershire, UK. Extractable Cu, Fe, and Mn was determined by Diethylene Triamine Pentaacetic Acid (DTPA) extractant method and extractable B was determined by water extractable B [21]. Nicotine was determined in these soils by spectrophotometric analysis using a UV visible single beam fixed at $602 \mathrm{~nm}$ [22].

\subsection{Statistical Analyses}

Statistical analyses (two factors: sites; Sikonge, Tabora, Urambo, and fertilization) were done using STATISTICA 8th Edition, StatSoft, Inc., Tulsa, OK, USA and analysis of variance (ANOVA). The significant means were compared using Fisher's least significance difference at $p=0.05$.

\section{Regression and Correlation Assessment}

Nicotine as a response variable $(\mathrm{Y})$ was regressed against $\mathrm{N}, \mathrm{K}, \mathrm{P}, \mathrm{Ca}, \mathrm{Mg}$, and $\mathrm{S}$ as constant macronutrients in the following model:

$$
\mathrm{Y}=\mathrm{z}_{1} \mathrm{~V}_{\mathrm{i}}+\mathrm{z}_{2} \mathrm{~V}_{\mathrm{ii}}+\mathrm{z}_{3} \mathrm{~V}_{\text {iii }}+\mathrm{z}_{4} \mathrm{~V}_{\mathrm{iv}}+\mathrm{z}_{5} \mathrm{~V}_{\mathrm{v}}+\mathrm{z}_{6} \mathrm{~V}_{\mathrm{vi}}+\mathrm{C}
$$

where $\mathrm{V}_{\mathrm{i}}$ to $\mathrm{V}_{\mathrm{vi}}$ stand for parameters $\mathrm{N}, \mathrm{K}, \mathrm{P}, \mathrm{Ca}, \mathrm{Mg}$, and $\mathrm{S}, \mathrm{z}_{1}$ to $\mathrm{z}_{6}$ represent coefficients of the parameters, $\mathrm{Y}$ is nicotine and $\mathrm{C}$ is the constant. 
Correlations of nicotine against $\mathrm{N}, \mathrm{K}, \mathrm{P}, \mathrm{Ca}, \mathrm{Mg}$, and $\mathrm{S}$ were carried out to quantify the association impact of released nicotine in soils on the macronutrients.

\section{Results and Discussion}

\subsection{Effects of Tobacco Cultivation and Fertilizer Application on Soil pH, OC, and Nicotine}

The soils from Sikonge and Urambo are characteristically loamy sand, while soils of Tabora are characteristically sand (Table 1). Ratings of the studied parameters in these soils are based on the descriptions compiled by Landon [23]. The soil pH in Tabora soil was strongly acid (5.1-5.5) and medium acid (5.6-6.0) in Sikonge and Urambo. The results of the effects of tobacco cultivation and fertilizer application on soil $\mathrm{pH}, \mathrm{OC}$, and nicotine are presented in Table 2. Soil $\mathrm{pH}$ differed significantly different across the sites. The soil pH of 5.79 was observed in Urambo, followed by Sikonge (5.58) and Tabora (5.47). Comparing the soil $\mathrm{pH}$ for the measurements taken before the establishment of tobacco in the field (5.75), and the records taken after fertilization with NPK and CAN (5.52), the soil pH reduced by 0.23 units whereas in unfertilized plots (5.57) there was a reduction of 0.18 units. Unfertilized tobacco cultivated soils had a higher $\mathrm{pH}$ (5.57) than the fertilized tobacco soils (5.52). The $\mathrm{NH}_{4}{ }^{+}$could attribute the acidic character of these soils as a source of $\mathrm{N}$ by $7.1 \%$ applied to the crop with NPK fertilizer, and $\mathrm{H}^{+}$might be a by-product of nitrification. The acid-forming cation could also have been added from rain and inherent parent material as there is no detailed soil classification done to ascertain the presence of sesquioxides of $\mathrm{Fe}^{3+}$ and/or $\mathrm{Al}^{3+}$ [24]. Besides the total $\mathrm{N}, \mathrm{Ca}$, and $\mathrm{Mg}$ which are very low, other macronutrients including $\mathrm{S}, \mathrm{P}$, and $\mathrm{K}$ in soils from all sites were medium to high, suggesting the likely effect of soil reaction on their availability $[25,26]$.

Furthermore, the results of this study showed significant interactions between sites and fertilizer application on soil $\mathrm{pH}$. The $\mathrm{pH}$ of Sikonge soils significantly reduced from 5.89 before the experiment to 5.44 and 5.41 after unfertilized and fertilized tobacco harvesting, respectively. Soil $\mathrm{pH}$ for Tabora was not affected significantly by tobacco cultivation and fertilization when compared with measurements taken before the field experimentation. At the Urambo site, the soil $\mathrm{pH}$ was reduced significantly by the fertilization (Figure 1). This reduction in soil $\mathrm{pH}$ could be due to the $\mathrm{H}^{+}$generated by nitrification and the acidification effects caused by the nicotine released by tobacco roots.

The organic carbon (OC) for Sikonge, Tabora, and Urambo were significantly different across the sites. The higher OC value was recorded in Sikonge $(0.32 \%)$ followed by Urambo $(0.25 \%)$ and Tabora $(0.15 \%)$. The OC in the soil decreased significantly by planting tobacco and supplying fertilizers (Table 2). For instance, there was a significant reduction in OC content from $0.25 \%$ to $0.23 \%$ by just cultivating tobacco and fertilizing tobacco with $\mathrm{N}_{10} \mathrm{P}_{18} \mathrm{~K}_{24}$ and CAN $27 \%$. Furthermore, significant interactions were observed between sites and cultivating tobacco and fertilizer application. OC for Sikonge was significantly higher than in the other two sites, probably due to variation in soil particles. The lowest organic matter content was reported in Tabora and followed by Urambo (Figure 2). 
Table 2. Selected soil properties of Sikonge, Tabora, and Urambo experimental sites before and after experiments.

\begin{tabular}{|c|c|c|c|c|c|c|c|c|c|}
\hline \multirow[t]{2}{*}{ Assessments } & \multicolumn{9}{|c|}{ Soil Measured Variables } \\
\hline & Soil pH & Organic Carbon & Nitrogen & Nicotine & Phosphorus & Sulphur & Potassium & Calcium & Magnesium \\
\hline & & \multicolumn{2}{|c|}{$(\%)$} & \multicolumn{3}{|c|}{$\left(\mathrm{mg} \mathrm{kg}^{-1}\right)$} & \multicolumn{3}{|c|}{$\left(\mathrm{cmol}(+) \mathrm{kg}^{-1}\right)$} \\
\hline \multicolumn{10}{|l|}{ Site: } \\
\hline Sikonge & $5.58 \pm 0.09 b$ & $0.32 \pm 0.01 \mathrm{a}$ & $0.06 \pm 0.00 \mathrm{a}$ & $5.93 \pm 1.92 \mathrm{a}$ & $37.87 \pm 1.42 \mathrm{a}$ & $4.80 \pm 1.08 \mathrm{a}$ & $0.52 \pm 0.00 \mathrm{a}$ & $1.56 \pm 0.09 a$ & $0.27 \pm 0.01 \mathrm{a}$ \\
\hline Tabora & $5.47 \pm 0.00 c$ & $0.15 \pm 0.01 \mathrm{c}$ & $0.04 \pm 0.00 \mathrm{~b}$ & $3.97 \pm 1.45 b$ & $28.14 \pm 6.32 c$ & $3.45 \pm 1.16 \mathrm{c}$ & $0.24 \pm 0.01 \mathrm{~b}$ & $0.95 \pm 0.00 \mathrm{c}$ & $0.21 \pm 0.01 \mathrm{~b}$ \\
\hline Urambo & $5.79 \pm 0.03 \mathrm{a}$ & $0.25 \pm 0.00 \mathrm{~b}$ & $0.04 \pm 0.00 \mathrm{~b}$ & $1.51 \pm 0.48 \mathrm{c}$ & $29.36 \pm 3.77 b$ & $3.52 \pm 1.17 \mathrm{~b}$ & $0.23 \pm 0.00 \mathrm{~b}$ & $1.25 \pm 0.21 b$ & $0.26 \pm 0.01 \mathrm{a}$ \\
\hline \multicolumn{10}{|l|}{ Treatment: } \\
\hline Soil before tobacco & $5.75 \pm 0.06 \mathrm{a}$ & $0.25 \pm 0.03 \mathrm{a}$ & $0.04 \pm 0.00 \mathrm{c}$ & $0.01 \pm 0.00 \mathrm{c}$ & $47.09 \pm 1.58 \mathrm{a}$ & $8.47 \pm 0.16 a$ & $0.36 \pm 0.04 \mathrm{a}$ & $0.60 \pm 0.18 c$ & $0.26 \pm 0.01 \mathrm{a}$ \\
\hline $\begin{array}{c}\text { Soil after } \\
\text { tobacco-unfertilized }\end{array}$ & $5.57 \pm 0.07 b$ & $0.23 \pm 0.02 b$ & $0.05 \pm 0.00 \mathrm{~b}$ & $2.71 \pm 0.52 b$ & $23.81 \pm 3.03 b$ & $1.59 \pm 0.24 \mathrm{c}$ & $0.32 \pm 0.05 b$ & $1.41 \pm 0.09 \mathrm{~b}$ & $0.23 \pm 0.01 \mathrm{~b}$ \\
\hline $\begin{array}{c}\text { Soil after } \\
\text { tobacco-fertilized }\end{array}$ & $5.52 \pm 0.05 b$ & $0.23 \pm 0.02 b$ & $0.06 \pm 0.00 \mathrm{a}$ & $8.69 \pm 1.44 \mathrm{a}$ & $24.56 \pm 2.77 b$ & $1.72 \pm 0.26 b$ & $0.31 \pm 0.05 b$ & $1.76 \pm 0.03 \mathrm{a}$ & $0.24 \pm 0.01 \mathrm{~b}$ \\
\hline \multicolumn{10}{|l|}{ Two-Way ANOVA F } \\
\hline \multicolumn{10}{|l|}{ Statistic } \\
\hline Site $(\mathrm{S})$ & $25.09 * * *$ & $297.91 * * *$ & $48.20^{* * *}$ & $543.63^{* * *}$ & $226.13^{* * *}$ & $2442.6^{* * *}$ & $1561.49^{* * *}$ & $112.34^{* * *}$ & $25.09^{* * *}$ \\
\hline Treatment $(\mathrm{T})$ & $12.74^{* * *}$ & $9.46^{* * *}$ & $35.00 * * *$ & $2180.80^{* * *}$ & $1426^{*} 42^{* * *}$ & $65,267.4^{* * *}$ & $31.20 * * *$ & $426.44^{* * *}$ & $6.73 * *$ \\
\hline $\mathrm{S} \times \mathrm{T}$ & $5.48^{* *}$ & $7.68^{* * *}$ & $2.3 \mathrm{~ns}$ & $242.32 * * *$ & $197.45^{* * *}$ & $42.5^{* * *}$ & $9.32 * * *$ & $37.19 * * *$ & $2.81 \mathrm{~ns}$ \\
\hline
\end{tabular}

Key: values presented are means $\pm \mathrm{SE}_{\mathrm{x}}$ (standard error of means); ${ }^{* * *}=$ significant at $p \leq 0.001$; ${ }^{* *}=$ significant at $p \leq 0.01$; ns $=$ non-significant. Means in the same category of evaluated interface sharing similar letter (s) do not differ significantly based on their respective standard error (SE) at $5 \%$ error rate. 


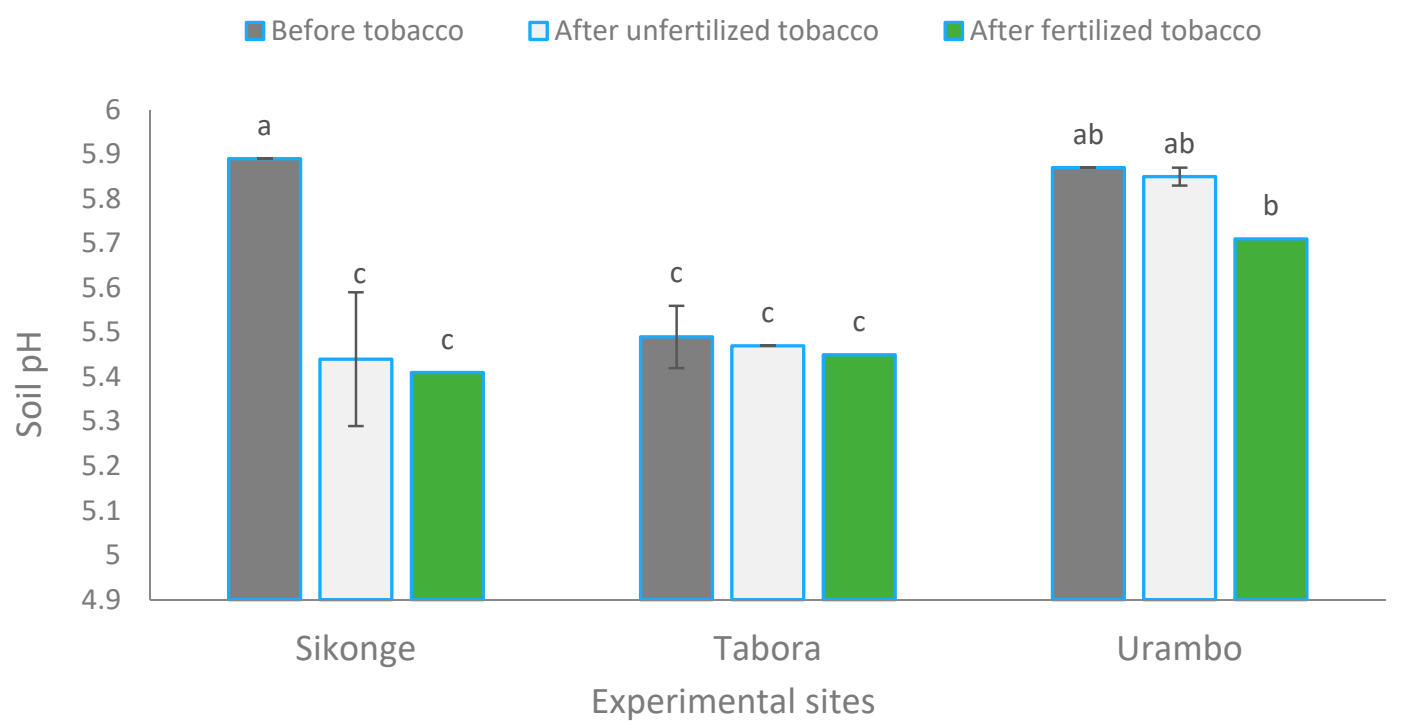

Figure 1. Effect of tobacco cultivation and fertilizer supply on soil pH. 'a' is very highly significant; 'ab' is very significant; ' $b$ ' is significant and ' $c$ ' non significant.

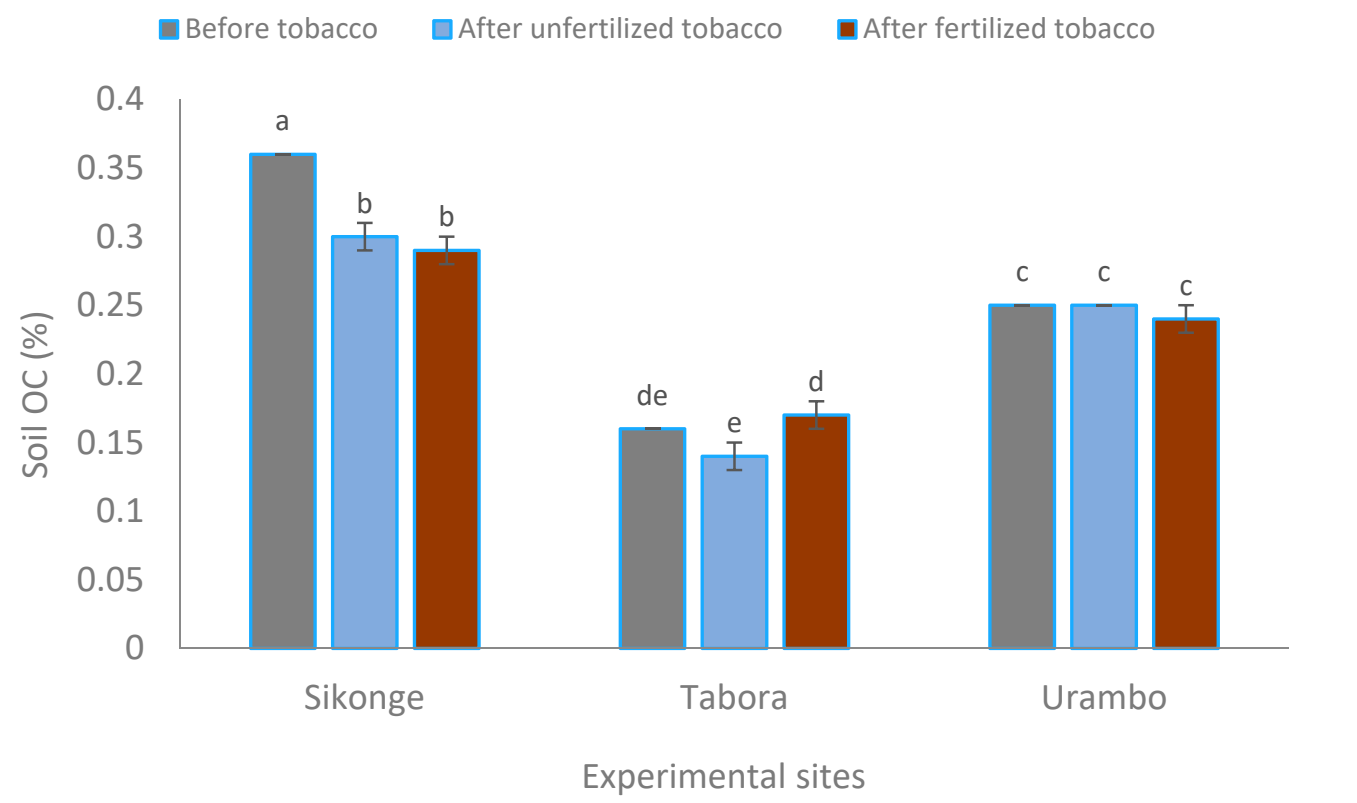

Figure 2. Effect of tobacco cultivation and fertilizer supply on soil organic carbon (OC). ' $a$ ' is very highly significant; 'b' is highly significant; 'c' \& 'd' are significant; ' $\mathrm{e}$ ' non significant.

The increase in soil total $\mathrm{N}$ was more pronounced in the loamy sand soil of Sikonge and Urambo, while in the sand soil series (Tabora) an increase in soil $\mathrm{N}$ was not observed. At this site, $\mathrm{N}$ could have been leached below the rooting and sampling zone following rainfall events. On the other hand, nicotine is also very water soluble, so it could have been leached too. The increase in soil total $\mathrm{N}$ in loamy sand soil could have been caused by the mineralization, nitrification, and nicotine released in the soils, that inhibited soil bacteria with a role of converting nitrate into the inorganic form and hence $\mathrm{N}$ mineralization rate reduced causing an increase of soil total $\mathrm{N}$ [5] as the leaching potential is lessened in the loamy sand. Furthermore, an increase of total $\mathrm{N}$ in these soils could be a result of released nicotine accumulation to the rhizosphere of which one of its forming components is $\mathrm{N}$. It is likely that the tobacco plant creates a favorable environment for increasing $\mathrm{N}$ in the rhizosphere as this nutrient is required for nicotine synthesis. 
Calcium increased in the soil media due to the increase in soil acidity, which decomposed OC thereby increasing Ca (Figure 2). Hermiyanto et al. [27] reported that OC has a significant impact in improving biological, physical, and chemical properties in the soil. Thus, nicotine released to the soil is impacting soil properties. Gulser et al. [28] observed changes in soil properties, including OC, in different incubation period after tobacco waste application, indicating that tobacco waste has the ability to modify soil properties. The increase in total $\mathrm{N}$ by $50 \%$ and exchangeable Ca by $193 \%$ was a direct result of NPK and CAN fertilization application. However, the tobacco effect on the increase in exchangeable Ca in the studied soil is by $135 \%$, and for NPK and CAN fertilization is only $193 \%$. The tobacco effect on increasing more exchangeable Ca in soil than NPK and CAN fertilization could be due to the ability of the tobacco plant increasing soil acidity, which hasten the decomposition of OC and release more $\mathrm{Ca}$ to the rhizosphere. Calcium also has been reported to have a direct positive effect on $\mathrm{N}$ uptake by tobacco plants [4] as $\mathrm{N}$ is an essential nutrient component for nicotine synthesis in tobacco roots. More work is needed to determine how $\mathrm{Ca}$ is being released.

Soil nicotine for Sikonge, Tabora, and Urambo were significantly different across the sites (Figure 3). The highest soil nicotine of $5.93 \mathrm{mg} \mathrm{kg}^{-1}$ was observed in Sikonge, followed by Tabora $\left(3.97 \mathrm{mg} \mathrm{kg}^{-1}\right)$ and Urambo $\left(1.51 \mathrm{mg} \mathrm{kg}^{-1}\right)$. Before the establishment of tobacco, soil nicotine was negligible $\left(0.01 \mathrm{mg} \mathrm{kg}^{-1}\right)$. However, after harvesting unfertilized tobacco, the soil nicotine increased to $2.71 \mathrm{mg} \mathrm{kg}^{-1}$. Upon tobacco fertilization with NPK and CAN, nicotine in soil increased significantly $(p<0.001)$ to $8.69 \mathrm{mg} \mathrm{kg}^{-1}$. Results showed significant interactions among sites and fertilizer application on soil nicotine. The highest increase of nicotine was observed in the Sikonge soil, with an increase from $0.01 \mathrm{mg} \mathrm{kg}^{-1}$ to 4.66 and $13.13 \mathrm{mg} \mathrm{kg}^{-1}$ for unfertilized and fertilized tobacco soils, respectively. Soil nicotine for Tabora soil increased from $0.01 \mathrm{mg} \mathrm{kg}^{-1}$ to 2.29 and $9.63 \mathrm{mg} \mathrm{kg}^{-1}$ for unfertilized and fertilized tobacco soils, respectively. The lowest increase of nicotine in soils observed in Urambo with an increase from 0.02 to 1.19 and $3.31 \mathrm{mg} \mathrm{kg}^{-1}$ for unfertilized and fertilized tobacco soils, respectively (Figure 3). Therefore, there was more nicotine in the soil following the fertilized treatments and the nicotine could be mineralized and contribute to legacy N. Xi et al. [29] associating a close relationship with $\mathrm{N}$ applied to the nicotine producing plant, of which may result in the increase of nicotine in soil through exudation.

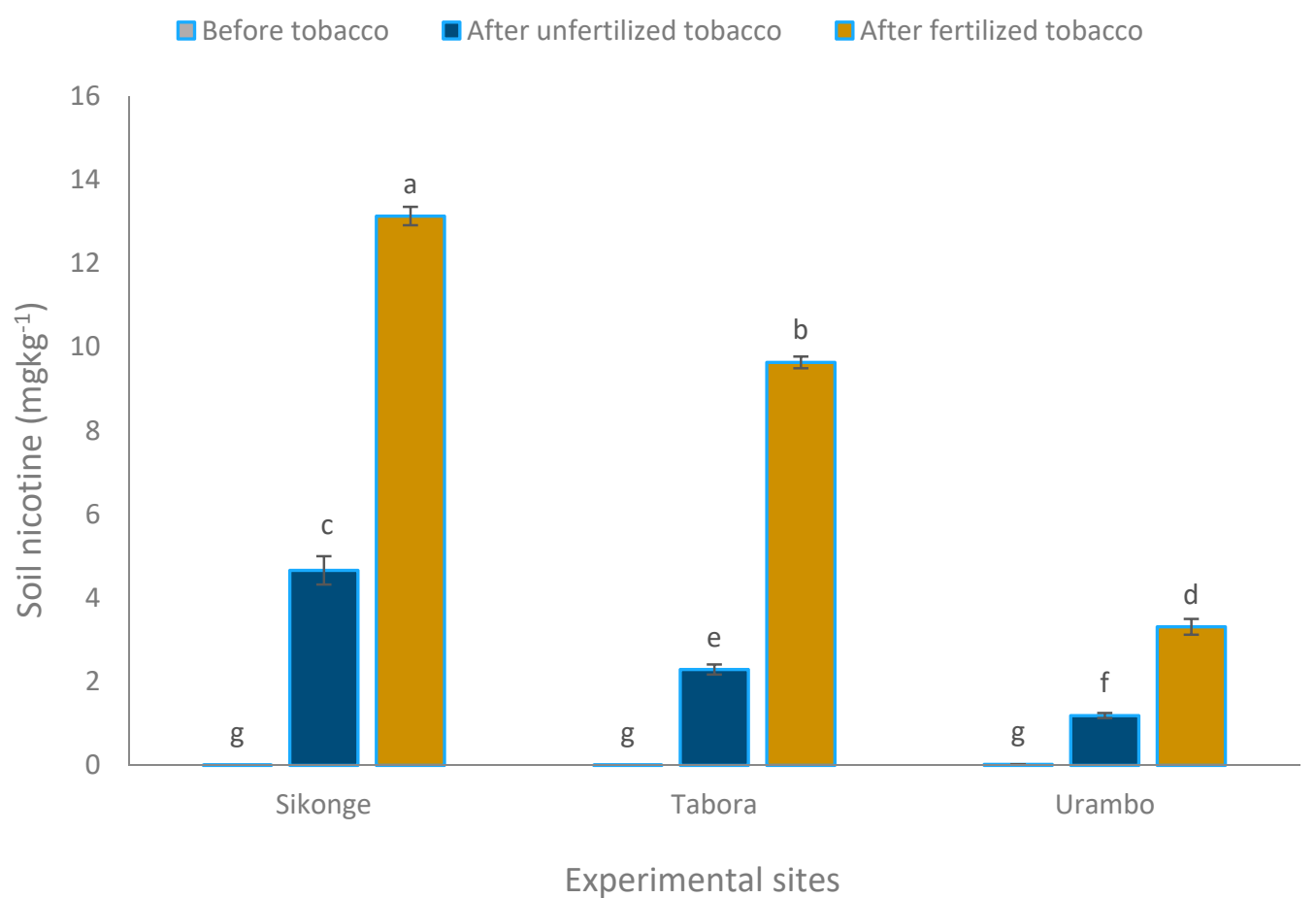

Figure 3. Effect of tobacco and fertilization on nicotine in soil. ' $a$ ' is very highly significant; ' $b$ ' is highly significant; 'c', 'd' 'e' \& 'f' are significant; 'g' non significant. 
The interactions of sites and soils with and/or without fertilization on soil $\mathrm{pH}, \mathrm{OC}$, nicotine, and macronutrients (P, S, K, and Ca) were significant (Table 2, Figures 1-7). This finding suggests that there is the high variability of these measured variables at various sites caused by tobacco cultivation and application of NPK and CAN fertilizers within a cropping season. Interactions between sites and fertilizers resulted in a significant reduction of soil $\mathrm{pH}$ in Sikonge but not in other sites. The low $\mathrm{pH}$ observed in Sikonge warrants further investigation. Residual nicotine increased significantly in tobacco cultivated soils with fertilization. The present study revealed that higher atmospheric temperatures $\left(25-29^{\circ} \mathrm{C}\right)$ could have resulted in the release of more nicotine to the rhizosphere [30].

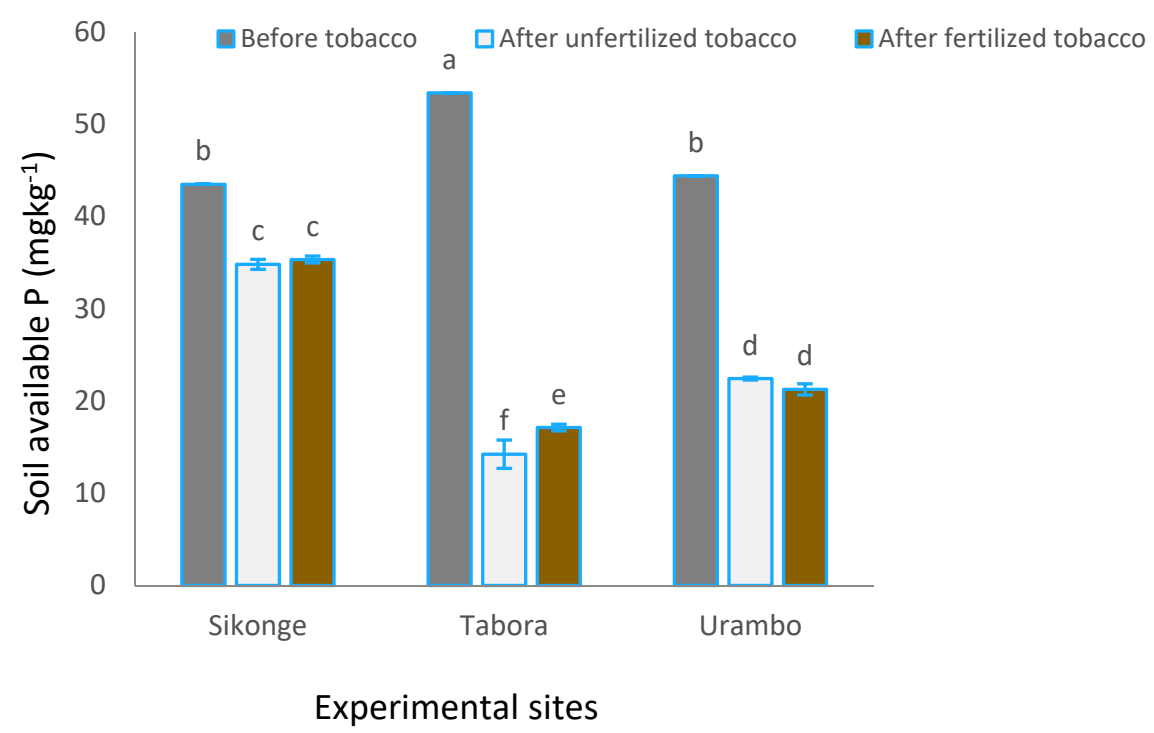

Figure 4. Effect of tobacco and fertilization on soil $P$. ' $a$ ' is very highly significant; ' $b$ ' is highly significant; 'c', 'd' \& 'e' are significant; 'f' non significant.

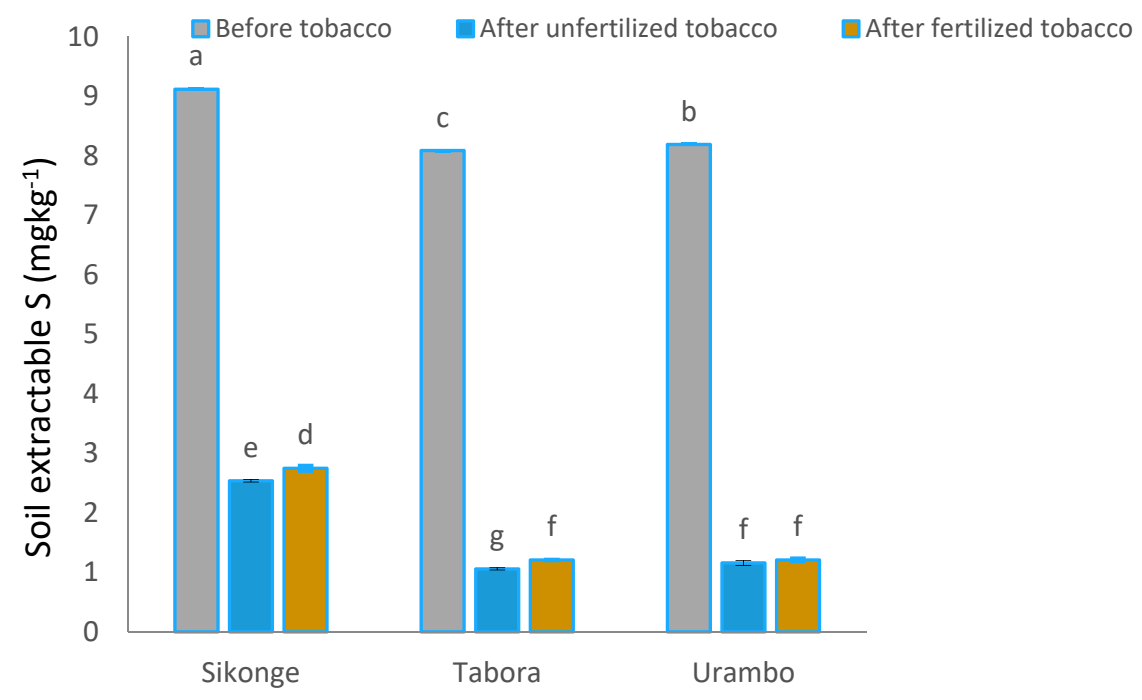

Experimental sites

Figure 5. Effect of tobacco and fertilization on soil $S$. ' $a$ ' is very highly significant; ' $b$ ' is highly significant; 'c', 'd' \& 'e' are significant; 'f' \& 'g' non significant. 


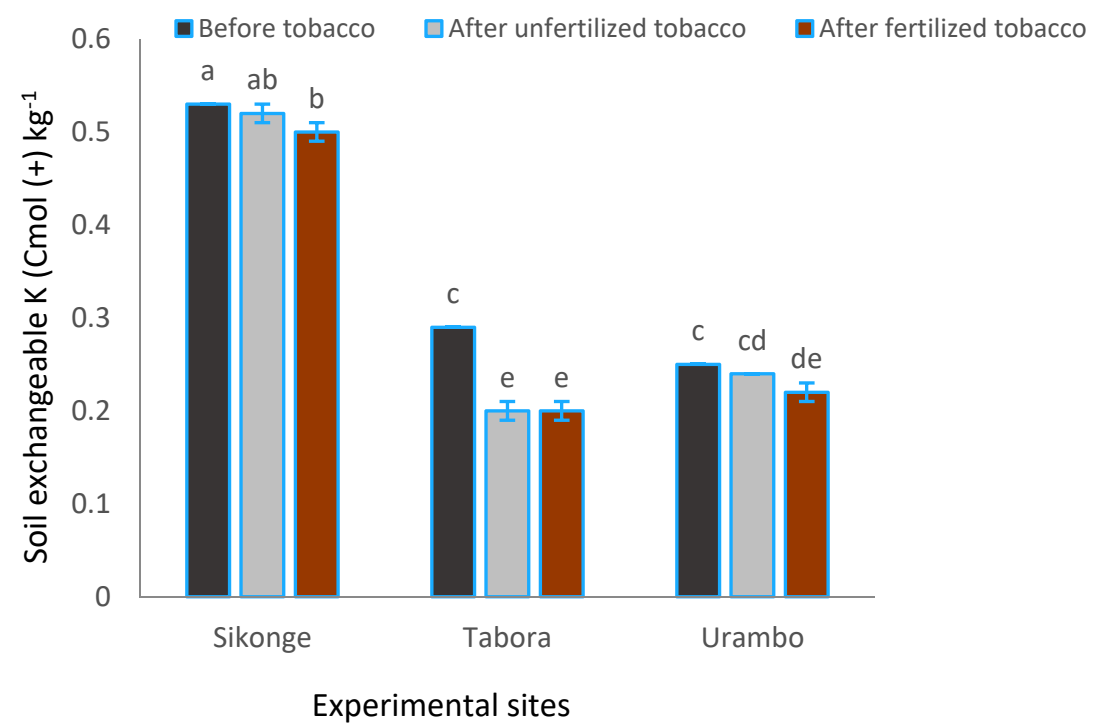

Figure 6. Effect of tobacco and fertilization on soil $\mathrm{K}$. ' $a$ ' \& 'ab' are very highly significant; ' $b$ ' is highly significant; 'c', \& 'cd' are significant; 'de' \& 'e' non significant.

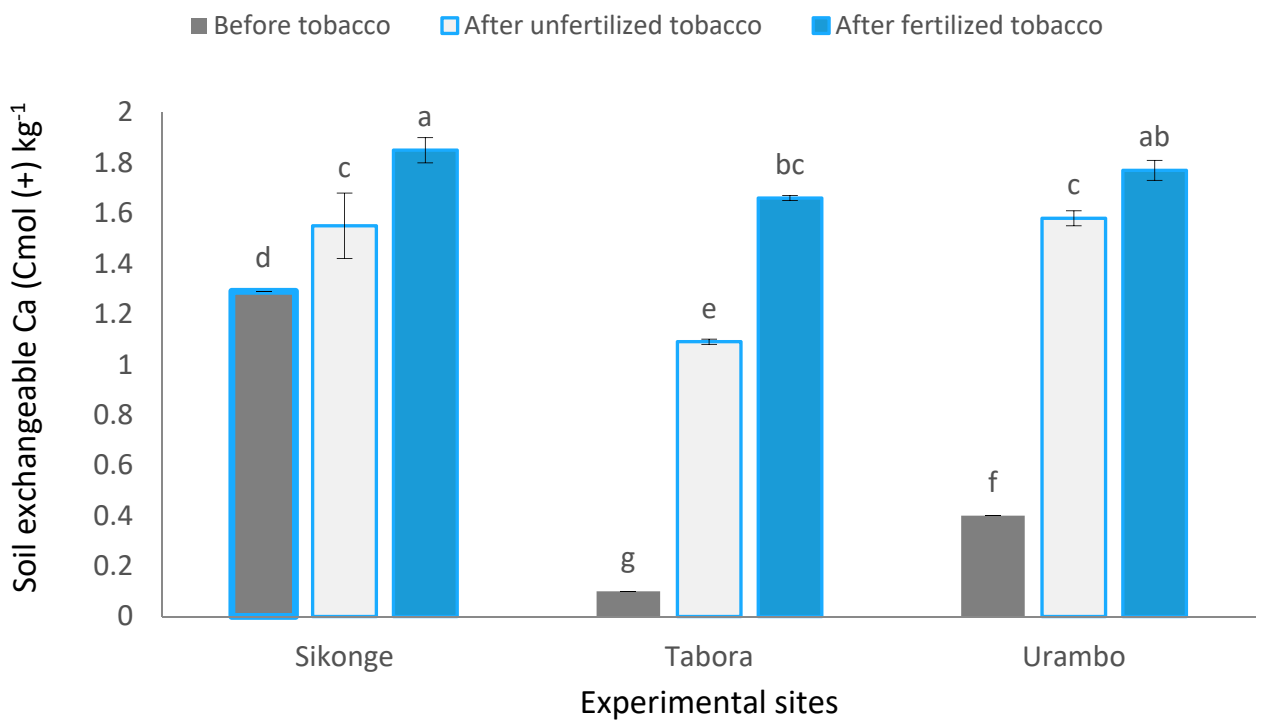

Figure 7. Effect of tobacco and fertilization on soil Ca. 'a' \& 'ab' are very highly significant; 'bc' \& 'c' are highly significant; 'd' \& 'e' are significant; 'f' \& ' $\mathrm{g}$ ' non significant.

\subsection{Effect of Tobacco Cultivation and Fertilizer Application on Soil Macronutrients}

Tobacco cultivated soils without fertilizer resulted in the reduction of soil S, P, Mg, and K, but the application of fertilizers increased the levels of these nutrients and $\mathrm{N}$ and $\mathrm{Ca}$ (Table 2). These findings suggest that in situations with no NPK and CAN application, the tobacco crop exhausted more nutrients, but under fertilization these nutrients are adequately absorbed. It is likely that despite their deficiencies in the soils, the availability of these nutrients were enhanced by the phyto-effect from tobacco roots $[13,14]$. Interestingly, fertilization in tobacco cultivated soils resulted in a decrease in soil available $\mathrm{P}$, extractable $\mathrm{S}$, exchangeable $\mathrm{K}$, and $\mathrm{Mg}$. The decrease of these nutrients in soils, when compared with unfertilized and fertilized scenarios, gave a signal that tobacco is a heavy nutrient feeder crop for these nutrients. This study revealed that the influence of tobacco on the increase in the rhizosphere macronutrients was in the order of $\mathrm{Ca}(135 \%)>\mathrm{N}(25 \%)$ and decrease in the order of $\mathrm{S}(81 \%)>\mathrm{P}(49 \%)>\mathrm{Mg}(12 \%)>\mathrm{K}(11 \%)$. In addition, the individual effects of NPK and CAN fertilizers on this rhizosphere increase is Ca $(25 \%)>\mathrm{N}(20 \%)>\mathrm{S}(8 \%)>\mathrm{Mg}(4 \%)>\mathrm{P}(3 \%)$ and only a 
decrease was observed in $\mathrm{K}(3 \%)$. Further, the influence of tobacco, NPK, and CAN fertilizers on the rhizosphere increase is $\mathrm{Ca}(193 \%)>\mathrm{N}(50 \%)$ while the decreased effect was on $\mathrm{S}(80 \%)>\mathrm{P}(48 \%)>\mathrm{K}$ $(14 \%)>\operatorname{Mg}(8 \%)$.

Soil N $(0.06 \%)$ for Sikonge was significantly $(p<0.001)$ higher when compared with total that of Tabora and Urambo $(0.04 \%)$ (Table 2$)$. Total soil $\mathrm{N}$ increased significantly $(p<0.001)$ from $0.04 \%$ to $0.05 \%$ and $0.06 \%$ in unfertilized and fertilized tobacco, respectively. The highest available soil $\mathrm{P}\left(37.87 \mathrm{mg} \mathrm{kg}^{-1}\right.$ ) was in Sikonge, followed by $29.36 \mathrm{mg} \mathrm{kg}^{-1}$ in Urambo and $28.14 \mathrm{mg} \mathrm{kg}^{-1}$ in Tabora. The available $\mathrm{P}$ was significantly $(p<0.001)$ reduced from 47.09 to 23.81 and $24.56 \mathrm{mg} \mathrm{kg}^{-1}$ in unfertilized and fertilized tobacco cultivated soils, respectively. Significant interactions between sites and fertilizer application was observed in this study. Available soil P in Sikonge was reduced significantly ( $p<0.001$ ) from $43.48 \mathrm{mg} \mathrm{kg}^{-1}$ before planting tobacco to $34.8 \mathrm{mg} \mathrm{kg}^{-1}$ in unfertilized tobacco soils. Before tobacco cultivation at the site, soil $\mathrm{P}$ was $53.31 \mathrm{mg} \mathrm{P} \mathrm{kg}^{-1}$ and was reduced to $14.22 \mathrm{mg} \mathrm{kg}^{-1}$ at the end of the season. In the Urambo soil, P decreased from 44.41 to $22.43 \mathrm{mg} \mathrm{kg}^{-1}$ before planting tobacco in unfertilized treatments (Figure 4). Therefore, these findings indicated that cultivation of tobacco caused a decrease in $\mathrm{P}$ and the decrease was higher when the plants were grown without fertilizers.

Extractable soil S followed a similar trend of P for Sikonge, Tabora, and Urambo (Table 2). Sikonge soil had significantly $(p<0.001)$ the highest $S\left(4.80 \mathrm{mg} \mathrm{kg}^{-1}\right)$ followed by Urambo $\left(3.52 \mathrm{mg} \mathrm{kg}^{-1}\right)$ and Tabora ( $3.45 \mathrm{mg} \mathrm{kg}^{-1}$ ) soils. The extractable $S$ was reduced from 8.47 to $1.59 \mathrm{mg} \mathrm{kg}^{-1}$ between uncultivated and cultivated tobacco in unfertilized soils. The cultivation of tobacco caused a decrease in extractable $S$, and the decrease was higher when the plants were grown without fertilizers. Interactions between sites and treatments indicated that extractable $S$ levels were significantly $(p<0.001)$ decreased in all sites after tobacco cultivation regardless of the fertilizer applications (Figure 5). Tobacco cultivation without fertilization resulted in the reduction of extractable $S$ from 9.12 to $1.06 \mathrm{mg} \mathrm{kg}^{-1}$ in all soils. The application of fertilizer in tobacco cultivated soils increased extractable $S$ from 2.74 to $1.21 \mathrm{mg}$ $\mathrm{kg}^{-1}$ relative to unfertilized tobacco cultivated soils where $S$ decreased from 2.54 to $1.06 \mathrm{mg} \mathrm{kg}^{-1}$. The decrease of soil S in unfertilized tobacco could be due to the high plant requirement of this nutrient for its metabolic activities [20].

Exchangeable $\mathrm{K}$ for Sikonge soil was significantly $(p<0.001)$ different when compared with Tabora and Urambo sites (Table 2). Exchangeable $\mathrm{K}$ in soils were $0.52,0.24$, and $0.23 \mathrm{cmol}(+) \mathrm{kg}^{-1}$ for Sikonge, Tabora, and Urambo, respectively. In soils where tobacco was cultivated without and with fertilization, the levels of $\mathrm{K}$ were reduced significantly. Exchangeable soil $\mathrm{K}$ was significantly higher in Sikonge (Figure 6). Application of fertilizer did not increase $\mathrm{K}$ levels in soil due to the genetic nature of tobacco plants requiring $\mathrm{K}$ for increasing leaf yield and quality [15].

Soil exchangeable Ca differed significantly $(p<0.001)$ across the sites where the highest $\left(1.56 \mathrm{cmol}(+) \mathrm{kg}^{-1}\right)$ was recorded in Sikonge (Table 2). Inclusion of tobacco significantly $(p<0.001)$ increased $\mathrm{Ca}$ in soils from 0.60 to 1.41 and $1.76 \mathrm{cmol}(+) \mathrm{kg}^{-1}$ in unfertilized and fertilized plots, respectively. Interactions between sites and treatments on Ca were significant (Figure 7). In all sites, soil exchangeable Ca was higher in fertilized tobacco. The increase in Ca in the unfertilized tobacco cultivated soils could be attributed to the mineralization of inherent $\mathrm{Ca}$ from parent material due to acidification caused by nicotine. Soil texture is an essential factor that determined concentrations of these macronutrients in tobacco plants and the differences observed [31].

The soil exchangeable $\mathrm{Mg}$ measured in Sikonge $\left(0.27 \mathrm{cmol}(+) \mathrm{kg}^{-1}\right)$ and Urambo $\left(0.26 \mathrm{cmol}(+) \mathrm{kg}^{-1}\right)$ was significantly $(p<0.001)$ higher than soil exchangeable $\mathrm{Mg}\left(0.21 \mathrm{cmol}(+) \mathrm{kg}^{-1}\right)$ of Tabora (Table 2). Further, soil Mg decreased significantly $(p<0.001)$ from $0.26 \mathrm{cmol}(+) \mathrm{kg}^{-1}$ in tobacco uncultivated soils to 0.23 and $0.24 \mathrm{cmol}(+) \mathrm{kg}^{-1}$ in unfertilized and fertilized plots, respectively. 


\subsection{Linear Regression and Correlation of Nicotine Contents in Soils and Macronutrients}

Multiple linear regressions analysis results are presented in Table 3. The generated model is as follows:

$$
\text { Nicotine }(\mathrm{Y})=21.57+327.29 \mathrm{~N}+47.71 \mathrm{~K}-15.96 \mathrm{Ca}-8.15 \mathrm{Mg}-1.46 \mathrm{~S}-0.61 \mathrm{P}
$$

with the coefficient of determination $\left(R^{2}\right)$ of 95 .

Table 3. A multiple linear regression analysis of nicotine as a response parameter and the measured macronutrients in soils.

\begin{tabular}{ccccccc}
\hline Fitted Parameters & Coefficients & Standard Error & t-Stat & $p$-Value & Lower 95\% & Upper 95\% \\
\hline Intercept & 21.570464 & 6.63464987 & 3.251183 & 0.007719 & 6.96769807 & 36.17322987 \\
$\mathrm{P}\left(\mathrm{mg} \mathrm{kg}^{-1}\right)$ & -0.60876671 & 0.174988087 & -3.4789 & 0.005158 & -0.99391289 & -0.22362052 \\
$\mathrm{~S}\left(\mathrm{mg} \mathrm{kg}^{-1}\right)$ & -1.46317501 & 0.501902323 & -2.91526 & 0.014056 & -2.567854574 & -0.35849545 \\
$\mathrm{~N}(\%)$ & 327.291899 & 97.86795681 & 3.344219 & 0.006544 & 111.8859781 & 542.697819 \\
$\mathrm{Ca}\left(\mathrm{cmol}(+) \mathrm{kg}^{-1}\right)$ & -15.9599962 & 3.972355713 & -4.01777 & 0.002024 & -24.70309214 & -7.2169002 \\
$\mathrm{Mg}\left(\mathrm{cmol}(+) \mathrm{kg}^{-1}\right)$ & -8.15136543 & 23.84940711 & -0.34178 & 0.738953 & -60.64355652 & 44.34082565 \\
$\mathrm{~K}\left(\mathrm{cmol}(+) \mathrm{kg}^{-1}\right)$ & 47.7142636 & 11.67659588 & 4.086316 & 0.001801 & 22.01424932 & 73.41427779 \\
\hline
\end{tabular}

The model 2 depicts that $\mathrm{N}$ and $\mathrm{K}$ were positively significant at $p=0.01$. However, a significant negative relationship ( $p=0.01$ ) was observed in nicotine levels against $\mathrm{Ca}, \mathrm{Mg}, \mathrm{S}$, and $\mathrm{P}$. The correlation between nicotine and soil $\mathrm{P}, \mathrm{S}, \mathrm{N}, \mathrm{Ca}, \mathrm{Mg}$, and $\mathrm{K}$ indicated a significant positive correlation of nicotine released in the rhizosphere with $\mathrm{N}, \mathrm{Ca}$, and $\mathrm{K}$ (Table 4). The negative correlation was observed between nicotine and $\mathrm{P}, \mathrm{S}$, and $\mathrm{Mg}$. Nicotine reduced the presence of $\mathrm{P}, \mathrm{S}$, and $\mathrm{Mg}$ in the soil following lowering soil acidity which increases solubility of $\mathrm{P}, \mathrm{S}$ and $\mathrm{Mg}$. Parallel to that mineralization of $\mathrm{N}$ is increased and its uptake as a precursor for nicotine synthesis, while also uptaking Ca to influence biomass production. However, mechanisms for nicotine in reducing the presence of certain nutrients prompt a need for further investigation.

Table 4. Correlations between nicotine and the measured macronutrients in soils.

\begin{tabular}{cccccccc}
\hline & $\mathbf{1}$ & $\mathbf{2}$ & $\mathbf{3}$ & $\mathbf{4}$ & $\mathbf{5}$ & $\mathbf{6}$ & $\mathbf{7}$ \\
\hline 1. Nicotine $\left(\mathrm{mg} \mathrm{kg}^{-1}\right)$ & 1 & & & & & & \\
2. $\mathrm{P}\left(\mathrm{mg} \mathrm{kg}^{-1}\right)$ & -0.58 & 1 & & & & & \\
3. S $\left(\mathrm{mg} \mathrm{kg}^{-1}\right)$ & -0.76 & 0.90 & 1 & & & & \\
$4 . \mathrm{N}(\%)$ & 0.84 & -0.42 & -0.59 & 1 & & & \\
5. $\mathrm{Ca}\left(\mathrm{cmol}(+) \mathrm{kg}^{-1}\right)$ & 0.72 & -0.80 & -0.78 & 0.79 & 1 & & \\
6. $\mathrm{Mg}\left(\mathrm{cmol}(+) \mathrm{kg}^{-1}\right)$ & -0.33 & 0.34 & 0.46 & 0.05 & 0.02 & 1 & \\
7. $\mathrm{K}\left(\mathrm{cmol}(+) \mathrm{kg}^{-1}\right)$ & 0.18 & 0.37 & 0.33 & 0.49 & 0.23 & 0.57 & 1 \\
\hline
\end{tabular}

\subsection{Effects of NPK and CAN Fertilization on Macronutrient Concentrations in Tobacco Leaves}

The tobacco leaf concentrations of macronutrients for $\mathrm{N}, \mathrm{P}, \mathrm{K}, \mathrm{S}, \mathrm{Ca}$, and $\mathrm{Mg}$ are presented in Table 5. Leaf N, Ca, and Mg differed significantly $(p<0.001)$ across the sites. Leaf K $(2.57 \%)$ in Urambo site was significantly $(p<0.001)$ higher when compared with Sikonge $(2.26 \%)$ and Tabora $(2.28 \%)$ sites, while leaf S $(0.29 \%)$ for Tabora was significantly $(p<0.001)$ higher in comparison to Sikonge $(0.22 \%)$ and Urambo $(0.20 \%)$ sites. Leaf $\mathrm{P}$ did not differ significantly across the sites. The data in Table 5 shows that the differences between $\mathrm{N}, \mathrm{P}, \mathrm{K}, \mathrm{S}, \mathrm{Ca}$, and $\mathrm{Mg}$ in the leaves of fertilized and unfertilized tobacco was significant. The initial $\mathrm{P}$ in soils at each site was adequate $\left(>25 \mathrm{mg} \mathrm{P} \mathrm{kg}^{-1}\right.$ soil) which is likely the reason why a response in foliar accumulation of $P$ was observed [32]. However, across the sites the observed significant differences as a response of tobacco to $\mathrm{P}$ application could be attributed to other factors including nutrient $\mathrm{P}$ imbalance with others (largely $\mathrm{N}, \mathrm{S}, \mathrm{K}, \mathrm{Fe}, \mathrm{Mn}$, and $\mathrm{B}$ ) and variation in rainfall and temperature during the crop growth periods [33]. 
Table 5. Macronutrient concentration (\%) in tobacco leaves harvested in fertilized and unfertilized soils.

\begin{tabular}{ccccccc}
\hline Factors & \multicolumn{7}{c}{ Measured Variables in Tobacco Leaves } \\
\hline & $\mathbf{N}$ & $\mathbf{P}$ & $\mathbf{K}$ & $\mathbf{C a}$ & $\mathbf{M g}$ & $\mathbf{S}$ \\
\hline Site: & & \multicolumn{7}{c}{$\mathbf{( \% )}$} \\
Sikonge & $2.14 \pm 0.11 \mathrm{a}$ & $0.12 \pm 0.02 \mathrm{a}$ & $2.26 \pm 0.19 \mathrm{~b}$ & $8.11 \pm 0.37 \mathrm{a}$ & $0.91 \pm 0.04 \mathrm{~b}$ & $0.22 \pm 0.03 \mathrm{~b}$ \\
Tabora & $1.55 \pm 0.03 \mathrm{c}$ & $0.12 \pm 0.02 \mathrm{a}$ & $2.28 \pm 0.23 \mathrm{~b}$ & $4.29 \pm 0.17 \mathrm{c}$ & $0.47 \pm 0.02 \mathrm{c}$ & $0.29 \pm 0.02 \mathrm{a}$ \\
Urambo & $1.64 \pm 0.10 \mathrm{~b}$ & $0.13 \pm 0.01 \mathrm{a}$ & $2.57 \pm 0.10 \mathrm{a}$ & $6.08 \pm 0.39 \mathrm{~b}$ & $1.54 \pm 0.04 \mathrm{a}$ & $0.20 \pm 0.01 \mathrm{~b}$ \\
\hline Treatments: & & & & & & \\
Unfertilized tobacco & $1.60 \pm 0.08 \mathrm{~b}$ & $0.11 \pm 0.01 \mathrm{~b}$ & $1.98 \pm 0.09 \mathrm{~b}$ & $5.49 \pm 0.49 \mathrm{~b}$ & $0.91 \pm 0.15 \mathrm{~b}$ & $0.20 \pm 0.02 \mathrm{~b}$ \\
Fertilized tobacco & $1.95 \pm 0.11 \mathrm{a}$ & $0.15 \pm 0.01 \mathrm{a}$ & $2.76 \pm 0.02 \mathrm{a}$ & $6.84 \pm 0.62 \mathrm{a}$ & $1.03 \pm 0.17 \mathrm{a}$ & $0.27 \pm 0.02 \mathrm{a}$ \\
\hline Two-Way ANOVA F-Statistics & & & & & & \\
Site (S) & $265.49^{* * *}$ & $0.0842 \mathrm{~ns}$ & $22.91^{* * *}$ & $426.61^{* * *}$ & $568.158^{* * *}$ & $7.60^{* *}$ \\
Treatment (T) & $235.33^{* * *}$ & $4.36^{*}$ & $334.97^{* * *}$ & $160.73^{* * *}$ & $22.807^{* * *}$ & $13.21^{* *}$ \\
S $\times$ T & $25.82^{* * *}$ & $1.34 \mathrm{~ns}$ & $17.28^{* * *}$ & $8.06^{* *}$ & $3.296 \mathrm{~ns}$ & $1.17 \mathrm{~ns}$ \\
\hline
\end{tabular}

Values presented are means $\pm \mathrm{SE}$ (standard error); ${ }^{* * *}, * * *$ significant at $p \leq 0.05, p \leq 0.01$, and $p<0.001$, respectively; $\mathrm{ns}=$ non-significant; means in the same category of evaluated interface sharing similar letter (s) do not differ significantly based on their respective least significance difference (LSD) value at $5 \%$ error rate. Leaf samples were collected when tobacco plants were about to flower.

Comparisons of leaf concentrations in fertilized and unfertilized tobacco results indicated that leaf concentrations for $\mathrm{N}, \mathrm{K}, \mathrm{Ca}$, and $\mathrm{S}$ increased significantly $(p<0.001)$ when fertilized. There was a significant increase in leaf $\mathrm{P}$ and $\mathrm{Mg}$ concentrations at $p<0.05$ and $p<0.001$ for unfertilized and fertilized tobacco, respectively. Results indicated that the interaction between sites and tobacco fertilization was significant for leaf $\mathrm{N}(p<0.001), \mathrm{K}(p<0.001)$, and Ca $(p=0.01)$ concentrations (Figure 8). However, there was no significant interaction on tobacco leaf concentrations of $\mathrm{P}, \mathrm{Mg}$, and $\mathrm{S}$.

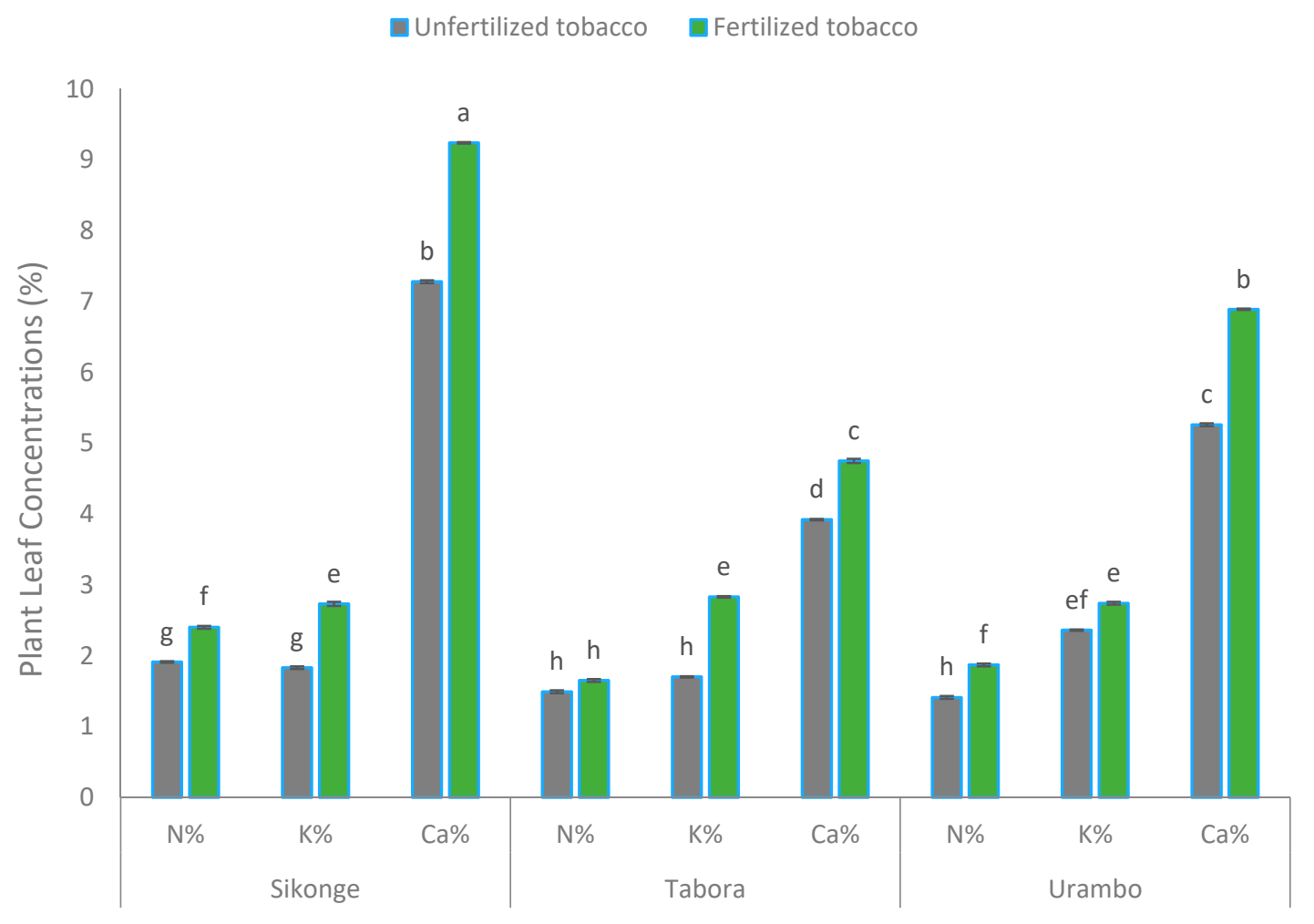

Experimental sites

Figure 8. Plant leaf $\mathrm{N}, \mathrm{K}$, and Ca concentrations upon fertilization across the sites. ' $\mathrm{a}$ ' is very highly significant; ' $b$ ' is highly significant; ' $c$ ' 'd' 'e' \& 'f' are significant; ' $g$ ' \& ' $h$ ' non significant. 
In fertilized tobacco plants, the leaf concentrations of $\mathrm{N}, \mathrm{P}, \mathrm{K}, \mathrm{Ca}, \mathrm{Mg}$, and $\mathrm{S}$ increased significantly compared with the quantities obtained in unfertilized plants (Table 5). The significant increase of these nutrients in leaves of fertilized plants is due to the applied NPK and CAN fertilizers, and is also attributed to the high tobacco requirements of these nutrients. Furthermore, inherently low levels to some of these nutrients in the studied soils and the likely synergism between $\mathrm{N}$ and $\mathrm{S}$ in the formation of amino acids could account for the leaf concentration increase [34]. As a result of fertilization, the tobacco leaf concentrations for $\mathrm{N}, \mathrm{P}, \mathrm{K}, \mathrm{Ca}, \mathrm{Mg}$, and $\mathrm{S}$ are all above the critical levels of $1.5 \% \mathrm{~N}$ given by Haghighi et al. [12], $0.1-1.0 \% \mathrm{P}, 1.6-4.1 \% \mathrm{~K}, 1.5-3.5 \% \mathrm{Ca}, 0.20-0.85 \% \mathrm{Mg}$, and $0.18-0.50 \% \mathrm{~S}$ given by Bryson and Mills [11]. However, further research is required to measure the mass of plant minerals as the leaf nutrient concentrations were at the adequate levels since this may give the actual amounts of nutrients taken-up by the tobacco plants from soils.

\section{Conclusions}

The application of NPK and CAN fertilizers improved growth of tobacco plants, and the crop released more nicotine to the rhizosphere, whereas exchangeable $\mathrm{Ca}^{2+}$ increased in the sand and loamy sand soil textures and total $\mathrm{N}$ only in loamy sand soils. The availability of $\mathrm{S}, \mathrm{P}, \mathrm{Mg}$, and $\mathrm{K}$ decreased in all soil textures, but fertilization increased the levels of these nutrients and nicotine, $\mathrm{N}$, and $\mathrm{Ca}$. The leaf concentrations of $\mathrm{Ca}, \mathrm{K}, \mathrm{P}, \mathrm{S}, \mathrm{N}$, and $\mathrm{Mg}$ increased significantly above the critical leaf levels upon fertilization with NPK and CAN. It is therefore likely that any subsequent crop after tobacco cultivation might benefit mainly from the increased $\mathrm{Ca}^{2+}$ and $\mathrm{N}$, although $\mathrm{N}$ is subject to various transformations.

Supplementary Materials: The following are available online at http://www.mdpi.com/2073-4395/10/3/418/s1, Table S1: Soil properties of the Sikonge site, Table S2: Soil properties of the Tabora site, Table S3: Soil properties of the Urambo site, Table S4: Leaf nicotine and tobacco leaf yield from three sites (Sikonge, Tabora, and Urambo), Table S5: Leaf nicotine concentrations and tobacco leaf yield of the Sikonge site, Table S6: Leaf nicotine concentrations and tobacco leaf yield of the Tabora site, Table S7: Leaf nicotine concentrations and tobacco leaf yield of the Urambo site.

Author Contributions: J.L. conceived the idea and research methodology, and performed the experiment; J.L., E.M., and P.N. analyzed data, and wrote and reviewed the manuscript. All authors have read and agreed to the published version of the manuscript.

Funding: This research was funded by grants from Tobacco Research Institute of Tanzania (TORITA) Department of Research through code 3001-DO1S02.

Acknowledgments: The authors appreciate the TORITA for financial support of this study and the Nelson Mandela African Institution of Science and Technology (NM-AIST) of Arusha Tanzania for providing authors doing the research.

Conflicts of Interest: The authors declare no conflict of interest in publishing this article.

\section{References}

1. Geist, H. Soil mining and societal responses: The case of tobacco in Eastern Miombo Highlands. In Coping with Changing Environments: Social Dimensions of Endangered Ecosystems in the Developing World; Routledge: Abingdon, UK, 1999; pp. 119-148.

2. Pius, Z.Y. Impact of small scale tobacco growing on the spatial and temporal distribution of Miombo woodlands in Western Tanzania. J. Ecol. Nat. Environ. 2010, 2, 10-16.

3. Hoyos, V.C.; Magnitskiy, S.; Plaza, G.T. Effect of fertilization on the contents of macronutrients and chlorine in tobacco leaves cv. flue-cured (Nicotiana tabacum L.) in two municipalities in Huila, Colombia. Agron. Colomb. 2015, 33, 174-183. [CrossRef]

4. López-Lefebre, L.R.; Rivero, R.M.; García, P.C.; Sanchez, E.; Ruiz, J.M.; Romero, L. Effect of calcium on mineral nutrient uptake and growth of tobacco. J. Sci. Food Agric. 2001, 81, 1334-1338. [CrossRef]

5. Farooq, M.; Husssain, T.; Wakeel, A.; Cheema, Z.A. Differential response of maize and mungbean to tobacco allelopathy. Exp. Agric. 2014, 50, 611-624. [CrossRef]

6. Xu, Z.C.; Wang, L.; Xiao, H.Q. pH distribution and relationship to soil nutrient in Hunan tobacco lands. Chin. J. Eco. Agric. 2008, 4, 6. [CrossRef] 
7. Moula, M.S.; Hossain, M.S.; Farazi, M.M.; Ali, M.H.; Mamun, M.A.A. Effects of consecutive two years tobacco cultivation on soil fertility status at Bheramara Upazilla in Kushtia District. J. Rice Res. 2018, 6, 190.

8. Marambe, B.; Sangakkara, R. Evaluation of different nitrogen fertilizer techniques on emergence and growth of tobacco (Nicotiana tabacum L.) seedlings. J. Agron. Crop Sci. 1988, 161, 273-276. [CrossRef]

9. Lu, Y.X.; Li, C.J.; Zhang, F.S. Transpiration, potassium uptake and flow in tobacco as affected by nitrogen forms and nutrient levels. Ann. Bot. 2005, 95, 991-998. [CrossRef]

10. Parker, R.G. Evaluation of Nitrogen Sources and Rates on Yield and Quality of Modern Flue-Cured Tobacco Cultivars. Ph.D. Thesis, North Carolina State University, Raleigh, NC, USA, 2009.

11. Bryson, G.; Mills, H. Plant Analysis Handbook IV; Micro-Macro Publishing: Athens, Greece, 2014.

12. Haghighi, H.; Daliri, M.S.; Mobaser, H.R.; Moosavi, A.A. Effect of different nitrogen and potassium fertilizer levels on quality and quantity yield of flue cured tobacco (Coker 347). World Appl. Sci. J. 2011, 15, 941-946.

13. Smith, W. Managing nutrients. In Flue-Cured Tobacco Guide; North Carolina State University: Raleigh, NC, USA, 2013; pp. 61-76.

14. Reed, T.D.; Johnson, C.S.; Semtner, P.J.; Wilkinson, C.A. Flue-Cured Tobacco Production Guide; Virginia Cooperative Extension Service; North Carolina State University: Raleigh, NC, USA, 2011.

15. Yang, T.Z.; Lu, L.M.; Xia, W.; Fan, J.H. Characteristics of potassium-enriched, flue-cured tobacco genotype in potassium absorption, accumulation, and in-ward potassium currents of root cortex. Agric. Sci. Chin. 2007, 6, 1479-1486. [CrossRef]

16. Vann, M.C.; Fisher, L.R.; Jordan, D.L.; Smith, W.D.; Hardy, D.H.; Stewart, A.M. The Effect of Potassium Rate on the Yield and Quality of Flue-Cured Tobacco (Nicotiana tabacum L.). Tob. Sci. 2012, 49, 14-20. [CrossRef]

17. Vann, M.C.; Fisher, L.R.; Jordan, D.L.; Smith, W.D.; Hardy, D.H.; Stewart, A.M. Potassium Rate and Application Effect on Flue-Cured Tobacco. Agron. J. 2013, 105, 304-310. [CrossRef]

18. Marschner, H. Mineral Nutrition of Higher Plants, 2nd ed.; Academic Press: San Diego, CA, USA, 1995.

19. Gurumurthy, K.T.; Vageesh, T.S. Leaf yield and nutrient uptake by FCV tobacco as influenced by $\mathrm{K}$ and $\mathrm{Mg}$ nutrition. Karnataka J. Agric. Sci. 2007, 20, 741-744.

20. Höller, K.; Király, L.; Künstler, A.; Müller, M.; Gullner, G.; Fattinger, M.; Zechmann, B. Enhanced glutathione metabolism is correlated with sulfur-induced resistance in Tobacco mosaic virus-infected genetically susceptible Nicotiana tabacum plants. Mol. Plant-Microbe Interact. 2010, 23, 1448-1459. [CrossRef]

21. Moberg, J.R. Soil and Plant Analysis Manual; The Royal Veterinary and Agricultural University, Chemistry Department: Copenhagen, Denmark, 2000.

22. Figueiredo, E.C.; de Oliveira, D.M.; de Siqueira, M.E.; Arruda, M.A. On-line molecularly imprinted solid-phase extraction for the selective spectrophotometric determination of nicotine in the urine of smokers. Anal. Chim. Acta. 2009, 635, 102-107. [CrossRef]

23. Landon, J.R. Booker Tropical Soil Manual. A Handbook for Soil Survey and Agricultural Land Evaluation in the Tropics and Subtropics; John Wiley \& Sons, Incorporation: New York, NY, USA, 1991; p. 474.

24. Hamarashid, N.H.; Othman, M.A.; Hussain, M.-A.-H. Effects of soil texture on chemical compositions, microbial populations and carbon mineralization in soil. Egypt. J. Exp. Biol. (Bot.) 2010, 6, 59-64.

25. Jensen, T.L. Soil $p H$ and the Availability of Plant Nutrients; International Plant Nutrition Institute (IPNI): Norcross, GA, USA, 2010.

26. Miller, J.O. Soil pH Affects Nutrient Availability. Fact Sheet FS-1054, July 2010. [CrossRef]

27. Hermiyanto, B.; Winarso, S.; Kusumandaru, W. Soil Chemical properties index of tobacco plantation land in Jember District. Agric. Agric. Sci. Proc. 2016, 9, 941-946. [CrossRef]

28. Gulser, C.; Demir, Z.; Ic, S. Changes in some soil properties at different incubation periods after tobacco waste application. J. Environ. Biol. 2010, 31, 671-674.

29. Xi, X.; Li, C.; Zhang, F. Tobacco plants can use nitrogen taken up before mechanical wounding to synthesize nicotine afterwards. Plant Signal Behav. 2008, 3, 87-90. [CrossRef]

30. Cheng, T.; Hu, L.; Wang, P.; Yang, X.; Peng, Y.; Lu, Y.; Chen, J.; Shi, J. Carbon monoxide potentiates high temperature-induced nicotine biosynthesis in tobacco. Int. J. Mol. Sci. 2018, 19, 188. [CrossRef]

31. Shakeel, S. Consideration of tobacco dust as organic amendment for soil: A soil and waste management strategy. Earth Sci. 2014, 3, 117-121. [CrossRef]

32. Rideout, J.W.; Gooden, D.T. Effects of starter fertilizer, granular phosphorus fertilizer, time of fertilization, and seedling phosphorus concentration on flue-cured tobacco growth and nutrition. Tob. Sci. 2000, 19-26. [CrossRef] 
33. Ali, F.; Ali, A.; Gul, H.; Sharif, M.; Sadiq, A.; Ahmed, A.; Ullah, A.; Mahar, A.; Kalhoro, S.A. Effect of boron soil application on nutrients efficiency in tobacco leaf. Am. J. Plant Sci. 2015, 6, 1391-1400. [CrossRef]

34. Marschner, H. Mineral Nutrition of Higher Plants, 3rd ed.; Academic Press: London, UK, 2012.

(C) 2020 by the authors. Licensee MDPI, Basel, Switzerland. This article is an open access article distributed under the terms and conditions of the Creative Commons Attribution (CC BY) license (http://creativecommons.org/licenses/by/4.0/). 